AGRICULTURE AND BIOLOGY JOURNAL OF NORTH AMERICA

ISSN Print: 2151-7517, ISSN Online: 2151-7525, doi:10.5251/abjna.2011.2.6.981.994

(C) 2011, ScienceHu $\beta$, http://www.scihub.org/ABJNA

\title{
Alarming occurrence of Fusarium wilt disease in pea (Pisum sativum L.) cultivations of Jabalpur district in Central India revealed by an array of pathogenicity tests
}

\author{
Poornima Sharma \\ Mata Gujri Women's College, Marhatal, Jabalpur, M.P., India. \\ poornima.sharma@rediffmail.com \\ ABSTRACT
}

\begin{abstract}
A survey of pea cultivations in Jabalpur district of India revealed predominance of Fusarium diseases in this region. This was confirmed by an array of pathogenicity tests involving pathogen spores and metabolites. Fusarium oxysporum FP-02/G [NFCCl-2195] isolated from Ghana village of Jabalpur district was found to show severe pathogenicity on pea varieties commonly grown in Jabalpur.
\end{abstract}

Keywords: Fusarium oxysporum, Pea, Susceptibility

wilt in Britain as a serious problem. Buxton (1958) stated that Fusarium oxysporum f. sp. pisi showed alteration in pathogenicity induced by root exudates of resistant host plant. Haware (1971) found that Fusarium spp. were among dominant fungi isolated from the five pea varieties evaluated in India. Clarkson (1978) evaluated pathogenicity of Fusarium spp. associated with foot rot of peas and beans. In another research, several plant species and their varieties were screened for susceptibility to Fusarium oxysporum f. sp. radicis-lycopersici and it was found that there were additions to the host range of this pathogen (Manzies and Koch, 1990). Similarly, Keinath (1994) studied pathogenicity and host range of Fusarium oxysporum isolated from sweet basil. Gordon and Martyn (1997) analysed the evolutionary biology of Fusarium oxysporum and stated that the possibility of one pathogenic race being converted to another can not be denied. In a study evaluating root rot of pea, thirty nine strains of Fusarium oxysporum were isolated from soil and ten strains were isolated from pea plants showing root rot from five locations on two neighbouring fields of pea. Twenty one of these were found to be pathogenic to pea (Skovgaard et al., 2002). These figures indicate the severity of Fusarium diseases on pea cultivations. Also, in the same research it was found that the pathogenic and the presumed non pathogenic strains were genetically very closely related.

Fusarium wilt and root rot diseases have been a problem for decades. Snyder in 1933 noticed that certain strains of Fusarium (Fusarium orthoceras var. pisi) causing wilt disease of pea showed different pathogenic capacities than usual. Padwick in 1938 analysed complex fungal rotting of pea seeds and isolated a number of Fusarium species, some of which were highly pathogenic to pea. Buxton and Storey (1954) also discussed the occurrence of pea

Recently, a number of new disease reports on Fusarium have been submitted to the literature pool on agricultural research as mentioned further. Not only new races and special forms but new species of Fusarium have also been discovered in recent times. Skovgaard et al., in 2003, identified Fusarium commune as a new species by morphological and 
molecular phylogenetic data . F. commune is closely related to, but phylogenetically independent of F. oxysporum. Polizzi et al. (2010) mentioned first occurrence of Fusarium wilt of Bougainvillea glabra caused by Fusarium oxysporum in Italy. Perveen and Bokhari (2010) published first report of Fusarium wilt of Lavandula pubescens caused by Fusarium oxysporum in Saudi Arabia. Felgueiras et al., 2010, reported Fusarium wilt caused by Fusarium oxysporum f. sp. basilici on Ocimum minimum in Portugal. Karaca and Kahveci (2010), published first report of Fusarium oxysporum f. sp. radiciscucumerinum on cucumbers in Turkey. The above mentioned literature strongly implicates that Fusarium diseases are a challenge to modern agricultural economy. Fusarium oxysporum has become a threat not only to agriculture but also to lives of animals as a novel case of severe Fusarium oxysporum infection in an Atlantic Bottlenose Dolphin (Tursiops truncatus) was reported by Staggs et al. (2010).

\section{MATERIALS AND METHODS}

Wilt and root rot afflicted pea plants were obtained from various pea fields of Jabalpur district and analysed in the laboratory. Pathogens isolated from various fields were tentatively identified and coded. Most of the suspected pathogens isolated from lesions of roots were Fusarium oxysporum and $F$. solani.

Confirming the Cause of Disease- Establishing Koch's Postulates: An array of pathogenicity tests were performed to reconfirm Koch's postulates on the suspected pathogen causing wilt disease of pea plantations in selected fields of Jabalpur in Madhya Pradesh, India. Fusarium oxysporum FP-02/G [NFCCl-2195] isolated from severely wilt afflicted fields of Ghana village of Jabalpur was employed in the series of pathogenicity tests in this research. Other Fusarium isolates were similarly tested. Methods have been used in modified form as per environmental conditions and availability of resources.

For all the experiments involving seeds of test plant, seeds were surface disinfected with $\mathrm{HgCl}_{2}, 0.05 \%$, for $15 \mathrm{sec}$. and washed several times with distilled water after short duration treatment with low concentration of sterilizing agent lest excess of chemical treatment might influence exudation from seeds.

Blotter test : Seeds collected from Fusarium infected mature plant samples obtained from various locations in and around Jabalpur were subjected to blotter test in two sets ; set 1 - surface sterilized seeds and set 2 - washed only with distilled water. Both the sets were rinsed several times with sterilized distilled water and separately placed in moist chamber prepared by placing sterilized moist filter paper in petri plate. The sets were incubated at $25^{\circ} \mathrm{C}$ and observed over a span of one week (Dhingra and Sinclair, 1995).

\section{Application of Pathogen Spores}

a. Water Agar Plate Test: Five varieties of pea were taken for this experiment: Arkel, Azad P3, PSM, JM and Local. Agar plates were spread with pathogen spore suspension of about $1 \times 10^{7} \mathrm{cfu} / \mathrm{ml}$. 15 pea seeds per variety were, thereafter, placed on each of these water agar plates, separately. The plates were incubated at $25^{\circ} \mathrm{C}$ for seven days and observed after every 24 hours. Infection of $F$. oxysporum on pea seeds of the selected varieties was studied and evaluated on a 30 point scale (modification of method by Ondrej et al., 2008; Gunawardena, 2005). If a germinated seed showed coat infection as well as radical tip infection then two points or if either was true then one point was given. Two points were given if a seed failed to germinate and showed coat infection as well. Total 30 points were allotted to 15 seeds per variety in case of maximum level of infection.

b. Artificial Infestation of Soil with Test Pathogen: The pathogen was allowed to sporulate on wheat bran- sand medium and a dense spore suspension was prepared of about $10^{7} \mathrm{cfu} / \mathrm{ml}$. About $25 \mathrm{gm}$ of autoclaved soil was inoculated with $10 \mathrm{ml}$ of spore suspension in a small earthen pot of about 30 $\mathrm{ml}$ capacity. One week old pea seedlings of Arkel variety were transplanted in this pathogen laden soil after two days. Observations were taken for the next 9 days. Comparisons were made with control seedlings in pathogen free pot (Dhingra and Sinclair, 1995).

c. Root Dip Method: In a variant of the above experiment, the roots of seedlings were mildly disinfected with $\mathrm{HgCl}_{2} \quad(0.05 \%, 15$ seconds) and washed several times in sterilized distilled water, thereafter, the seedling roots were dipped in pathogen spore suspension for five hours and then transplanted in sterile soil (Dhingra and Sinclair, 1995).

Application of Pathogen Metabolites through Cell Free Culture Filtrate (CFCF): Pathogen was inoculated in Czapek Dox broth medium (Titan Biotech, TM368, Batch 381073) and incubated for 10 days at $25^{\circ} \mathrm{C}$ with alternate $12 \mathrm{~h}$ light and dark period. 
The broth was filtered under aseptic conditions to obtain CFCF. Ten day old Arkel pea seedlings with cotyledons were washed gently under tap water, mildly surface disinfected then rinsed several times in sterilized distilled water. The roots of seedlings were dipped in vials containing $15 \mathrm{ml}$ of undiluted CFCF. For comparison, uninoculated medium and distilled water were used in the control vials in place of CFCF. Observations were taken every half an hour. Symptoms were recorded and results interpreted (Ravikumar and Babu, 2007; Dhingra and Sinclair, 1995).

Direct Seed to Seed Transfer of Pathogen: Fresh surface disinfected 20-25 seeds of pea were placed in transparent polyethylene bags. In each bag, three week under-storage Fusarium infested pea seed was introduced. Observations were taken to check seed to seed transfer of pathogen and the speed of proliferation. The bags were incubated at $25^{\circ} \mathrm{C}$ at $80 \%$ relative humidity and alternate $12 \mathrm{~h}$ light and dark periods. Observations were taken daily for about a week.

Microscopic Study of Infected Root Tip: Root tip of pathogen infected pea sprout was cut transversely by 2-3 $\mathrm{mm}$ length and placed on a microscopic slide with a drop of cotton blue stain under cover-slip. The tissue being soft could be gently pressed under the cover-slip. Same procedure was followed for root tip

Table 1: Isolation of Suspected Pathogen from Diseased Plant Roots

\begin{tabular}{|l|l|l|}
\hline Field location (Name of Farmer) & Sample code & $\begin{array}{l}\text { Most frequently isolated fungal } \\
\text { genera from diseased pea roots }\end{array}$ \\
\hline Ghana (Achchelal) & $\mathrm{P}-01$ & Fusarium sp. \\
\hline Ghana (Rajjan Patel) & $\mathrm{P}-02$ & Fusarium sp. \\
\hline Tilhari (Govind Patel) & $\mathrm{P}-03$ & Fusarium sp. \\
\hline Seoni (Girdhari Patel) & $\mathrm{P}-04$ & Rhizoctonia sp. \\
\hline Shahpura (Shiv varan) & $\mathrm{P}-05$ & Fusarium sp. \\
\hline Puraina Road (Bhaiyajee Patel) & $\mathrm{P}-06$ & Fusarium sp. \\
\hline Amkhera (Satish Patel) & $\mathrm{P}-07$ & Fusarium sp. \\
\hline Puraina Road (Shankar lal) & $\mathrm{P}-08$ & Mixed \\
\hline Amkhera (Sandeep Patel) & $\mathrm{P}-09$ & Pythium sp. \\
\hline Tilgava (Santosh Yadav) & $\mathrm{P}-10$ & Pythium sp. \\
\hline Amkhera (Ambika Patel) & $\mathrm{P}-11$ & Mixed \\
\hline Patan (Brij Raj Singh) & $\mathrm{P}-12$ & Fusarium sp. \\
\hline Tilhari (Nonelal Patel) & $\mathrm{P}-13$ & Fusarium sp. \\
\hline Patan (Akhilesh Jain) & $\mathrm{P}-14$ & Fusarium sp. \\
\hline
\end{tabular}

Most of the diseased plants in fields of Jabalpur showed occurrence of Fusarium species. There are reports which state that Fusarium is capable of remaining in soil for a number of years in the form of of healthy pea sprout. Microscopic observations were recorded.

Determining Alternate Harbours: Crops commonly grown in the fields of Jabalpur surveyed in this research were tested for their susceptibility to the pathogen under study. Pathogenicity test no. 2a (application of pathogen spore) and no. 3 (metabolite test) were performed on the seeds and seedlings of these crops and results were interpreted.

Identification of the Pathogen: Pathogen was identified by studying cultural characteristics and microscopic features (Leslie and Summerell., 2006; Watanabe, 2002; Summerell et al., 2003; Gagkaeva, 2008). The pathogen sample was also sent to Fungal Identification Service, ARI, Pune, India for confirmation of its identity and deposition.

\section{RESULTS}

Isolation of Suspected Pathogen from Diseased Plant Roots: The diseased pea plant samples were externally examined for characteristic symptoms and subjected to pathogen isolation procedure. Rhizoplane of diseased roots showed emergence of fungi which were isolated and maintained on PDA slants. Especially, the lesion areas of roots with characteristic brown rot showed emergence of fungi which were later identified to be Fusarium (table 1). Considerable percentage of Fusarium was found in rhizosphere soil of these plants when analyzed for microbial load. chlamydospores. On availability of its host, it can germinate under suitable conditions and infect the host plant (Kraft, 1994). 
The series of pathogenicity tests confirmed that the popular varieties of pea grown in this region are susceptible to Fusarium diseases.

\section{Confirming the Cause of Disease}

Blotter Test on Pea Seeds to Detect Presence of Pathogen: Emergence of Fusarium was observed in five of thirty five surface disinfected seeds (set 1) and four of thirty five untreated distilled water rinsed seeds (set 2). The results noted between 48 to 72 hours did not show considerable difference between the two sets. On an average $12.9 \%$ of seeds were carriers of Fusarium. The test revealed that there is a possibility of seeds harbouring the pathogen if obtained from Fusarium disease afflicted plants (figure 1). The surface disinfected seeds also showed emergence of Fusarium, which means, the pathogen can harbour within the seed as well.

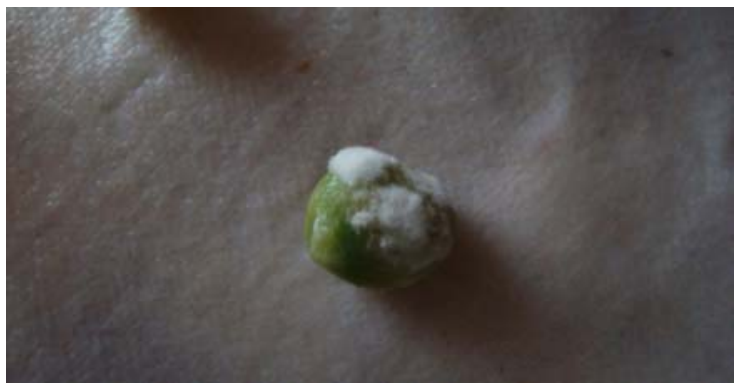

Fig 1: Blotter Test- Emergence of Fusarium sp. from coat of pea seed after about 2 days. Test seeds were taken from pods of Fusarium afflicted mature plants.

Fusarium might be transferred from roots through the vascular system to the seeds in advanced stages of infection. Another scope is through contamination of pods with Fusarium laden soil while harvesting or through wind. Seeds collected from infected plants may transfer the pathogen from one field to another through long distances, in case

they harbour the pathogen spores and hyphae. It has been established by researchers over a period of time that $F$. oxysporum f. sp. pisi can be transmitted occasionally by seed when harvested from a wilt infested field (Snyder, 1932; Kraft, 1994). Agarwal and Sinclair (1987) mentioned that Fusarium oxysporum could be a seed borne pathogen under circumstances where the fungus reaches and infects the embryo through the flower.
Hayat et al., 2005, agreed to the fact that seed borne infections, especially those caused by fungal pathogens, are a potential threat to pea production. F. oxysporum f. sp. pisi was an important fungus isolated from the seeds of at least three varieties of pea studied by these researchers in North West Frontier Province, Pakistan.

In a research conducted by Marcinkowska (2008) in Poland, $F$. oxysporum was one of the species among several other species of Fusarium isolated from seeds of pea from seven different cultivars, over a span of three consecutive years.

Masheshwari et al. (1982) isolated F. oxysporum f. sp. pisi from surface disinfected seeds of six varieties grown in Hoshiarpur district of Punjab, India. The isolates of $F$. oxysporum recovered were pathogenic. It was reported by the authors that the probability of seed transmission of the race 2 pathogen, which attacks pea plant at flowering to pod development stage, is much higher. Also, when considering other legumes, studies conducted by Pande et al. (2007) on chickpea indicates that $F$. oxysporum f. sp. ciceris can be an important seed borne pathogen.

\section{Application of Pathogen Spores}

a. Water Agar Plate Test: Five varieties of pea taken for this experiment showed considerable difference in response to the pathogen (table 2). All the varieties of pea seeds selected for the experiment showed varying percentage of seed coat and radical infection equivalent to degree of susceptibility to $F$. oxysporum FP-02/G. Maximum number of seeds germinated as the infection process initiated on the seed coats. But, as observed in Local variety of pea, seeds which showed total coverage by Fusarium mycelia were unable to germinate probably because the embryonic axis was infected before germination could start. Azad P3 showed least level of susceptibility to $F$. oxysporum, where as, Local pea variety was the most susceptible variety showing no resistance to the pathogen at all; followed by Arkel (figure 2) which is the most popular variety in this area (Jabalpur and around), and then followed by PSM and JM. In some cases, emerging radical showed browning of tip, in some other cases, extending roots also showed brown lesions (figure $3)$. 
Table 2: Pathogenicity Test by Application of Pathogen Spores on Pea Seeds (Water Agar Plate Test)

\begin{tabular}{|c|c|c|c|c|c|}
\hline $\begin{array}{l}\text { Seed variety } \\
\text { (15 seeds per } \\
\text { plate) }\end{array}$ & $\begin{array}{l}\text { Number of } \\
\text { seeds } \\
\text { germinated }\end{array}$ & $\begin{array}{l}\text { A. Number of } \\
\text { seeds showing } \\
\text { infected coat }\end{array}$ & $\begin{array}{l}\text { B. Number of seeds } \\
\text { showing infected } \\
\text { radical tips }\end{array}$ & $\begin{array}{l}\text { A+B (total score } \\
\text { on a } 30 \text { point } \\
\text { scale) }\end{array}$ & Infectivity \% \\
\hline Arkel & 15 & 7 & 5 & 12 & 40 \\
\hline Azad P3 & 14 & 2 & 4 & 6 & 20 \\
\hline PSM & 15 & 4 & 7 & 11 & 36.6 \\
\hline JM & 15 & 2 & 9 & 11 & 36.6 \\
\hline Local & 7 & 15 & 15 & 30 & 100 \\
\hline
\end{tabular}

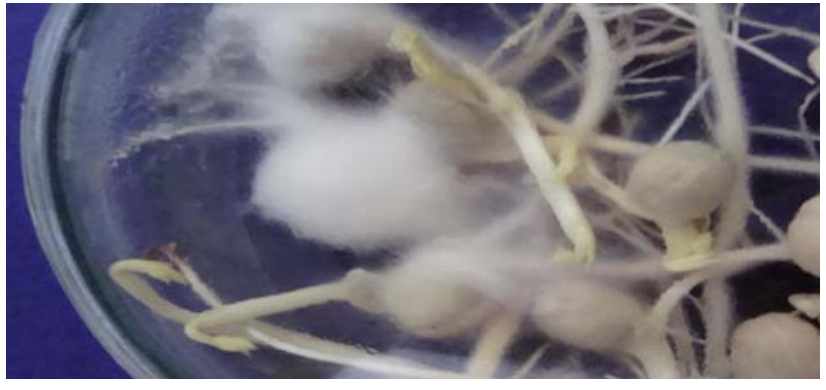

Fig 2: Pathogenicity test by pathogen spore application on seeds of pea variety- Arkel. Seed coat of pea infected by Fusarium oxysporum shows profuse mycelial growth.

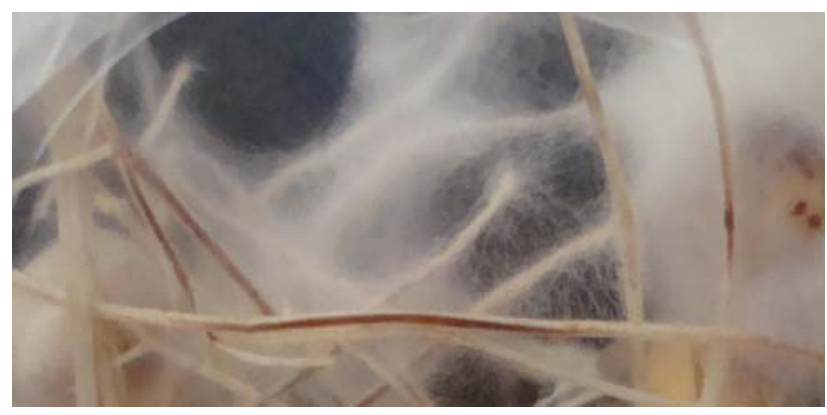

Fig 3: Roots from germinated pea seeds show characteristic brown lesions. Also, tender root branches are completely covered with mycelia of pathogen indicating severity of infection.

b. Seedling Test in Soil Artificially Infested with Test Pathogen and c. Seedling Test by Root Dip Method: Similar results were recorded in both the sub sets (b and $c$ ) of the experiment. Within a span of three to four days symptoms of wilt and yellowing in leaflets and stem began to develop in experimental seedlings; the symptoms were observed first in the lower parts which further extended towards the apex. Stunted growth was also a prominent symptom. Seedlings became flaccid and drooping down of stem was noticed (figure 4).



Fig 4: Wilt symptoms visible in pea seedlings planted in Fusarium laden soil as observed after one week.

On uprooting the seedlings after nine days, characteristic brown lesions were observed on the roots and cotyledons (figure 6). Characteristic brown rot was observed in hypocotyl and epicotyl regions of seedlings (figure 10). Root Dip method of pathogenicity test also confirmed the effect of $F$. oxysporum FP-02/G as noticed by comparing roots before and after exposure to pathogen (figure 8 and 9). F. oxysporum was recovered from lesion areas of diseased roots when suspensions prepared from root washings of infected plants and debris from lesions were spread on Potato Dextrose Agar medium. On the contrary, the control mini-pot showed healthy seedlings, turgid shoots with increased height and green foliage. Roots were also healthy long and branched (figure 5 and 7 ).



Fig 5: Healthy seedlings of pea planted in sterilized soil as observed after one week 


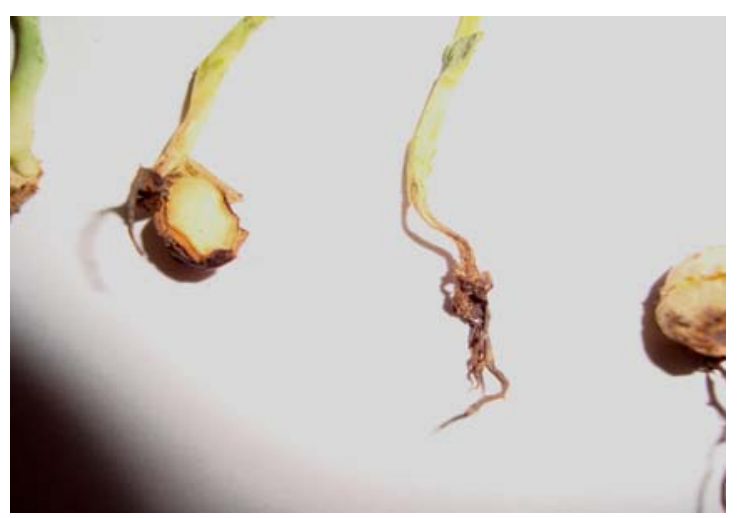

Fig 6: Seedlings showing characteristic symptoms of Fusarium root rot and wilt disease.

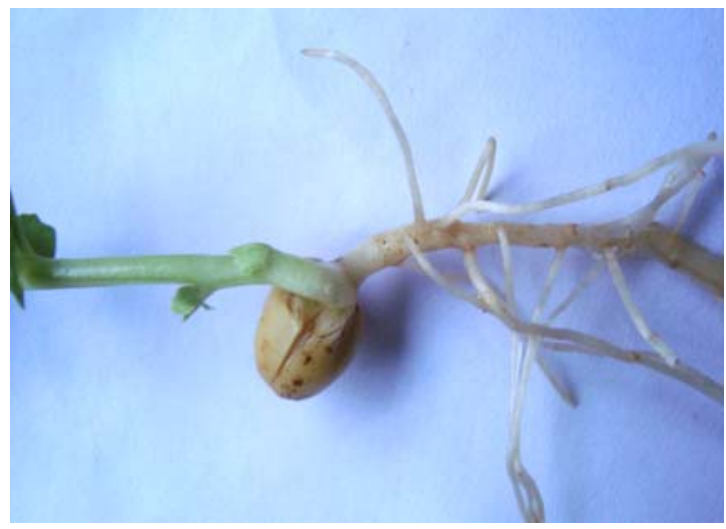

Fig 7: Healthy roots of a seedling from sterilized soil showing extended lateral branches.

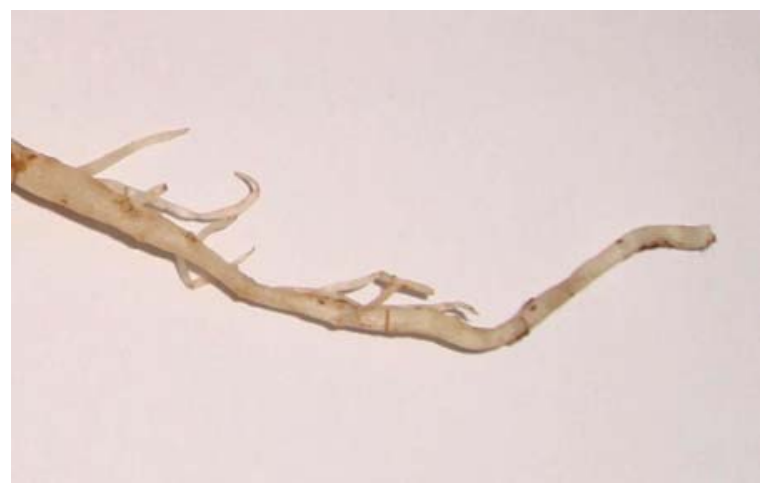

Fig 8: Healthy root of pea seedling before pathogenicity test by root dip assay.



Fig 9: Severely infected root of pea seedling as observed after pathogenicity test by root dip assay.

In 'Water Agar Plate Test' (table 2), the reason for high level of susceptibility shown by Arkel could be repeated sowing of the same variety of pea in the Fusarium laden soil. With time, this practice might have rendered this pea variety susceptible to the pathogen Fusarium oxysporum which is known to show considerable mutability (Buxton, 1958; Leslie and Summerell, 2006).

Short and Lacy (1974) observed that spores of Fusarium germinate within 24 hours in a seven $\mathrm{mm}$ radius of a germinating seed of pea under the influence of seed exudates.

It is established that for root-pathogen interactions to begin, the dormant propagules of pathogen must be activated by seed and root exudates which contain stimulatory substances; in the absence of such stimulatory substances infection of the host is not initiated in most cases. These exudates contain soluble (mainly sugars and amino acids) and volatile chemicals released from germinating seeds and actively growing roots which act as stimuli for infection process (Nelson, 1991). Gunawardena (2005) stated that flavonoids and isoflavonoids commonly present in the exudates of legumes may also be responsible for instigating Fusarium infection. Stasz et al. (1980) discussed the importance of seed coat in rendering pea varieties resistant or susceptible to pathogens such as Fusarium and Pythium. These researchers studied the level of inhibition shown to pathogens by seed coat extracts prepared from different pea varieties. They found that varying levels of responses were recorded ranging from highly resistant to susceptible pea varieties.

'Seedling Test in Soil Artificially Infested with Test Pathogen' and 'Seedling Test by Root Dip Method' reconfirmed wilt symptoms caused by Fusarium. 
These symptoms were in complete compliance with those mentioned by Kraft (1994). In 1990, Tessier et al. reported that wilting and necrosis of plant is associated with extensive fungal colonization of the vascular bundles. They also stated that vascular responses of the host to infection include vessel occlusion by gels (composed of carbohydrates, protein and pectin), deposition of callose in some xylem parenchyma cells and extensive vascular browning.

Pathogenic forms of $F$. oxysporum are reported to penetrate a host root either through wounds or directly through root apices (Nelson, 1981). The most common point of entry into the pea plant by the Fusarium wilt pathogen are the undifferentiated region of the root tips and the cotyledonary node (Kraft, 1994).

Most plants produce antimicrobial secondary metabolites in response to pathogen attack or stress (Lattanzio et al., 2006). Morrissey and Osbourn (1999) interpreted that induced antifungal compounds (phytoalexins) are synthesized in response to pathogen attack or stress as part of the plant defence mechanism only and are not present in healthy plants. These defence compounds are restricted to the tissue colonized by the fungus and cells surrounding the site of infection. Pisatin is an isoflavonoid phytoalexin and it is produced by pea in defense against fungal infection. The capability of Fusarium oxysporum to infect and cause disease in pea is considerably based on its ability to detoxify this phytoalexin by its demethylation to hydroxymaackiain, which means pisatin detoxification is directly related to pathogenicity of $F$. oxysporum and other pathogens of pea (Morrissey and Osbourn, 1999).

Application of Pathogen Metabolites (through Cell Free Culture Filtrate): CFCF of F. oxysporum FP-02/G was examined for its effect on ten day old pea seedlings. Symptoms of wilt began within 30 min. of experiment in the treated seedlings. The Table 3: Pathogenicity Test by Application of Pathogen Metabolites (through Cell Free Culture Filtrate)

\begin{tabular}{|c|c|c|c|}
\hline \multirow{2}{*}{$\begin{array}{l}\text { Time } \\
\text { Hours } \\
\text { /Minutes }\end{array}$} & \multicolumn{3}{|l|}{ Symptom (Wilting) } \\
\hline & Experimental set & control-medium & control-distilled water \\
\hline $0 \mathrm{~h}$ & nw & nw & nw \\
\hline $30 \mathrm{~min}$ & Visible symptoms of wilt begin & nw & nw \\
\hline $3 \mathrm{~h}$ & Further wilting and stooping down. Flaccid & nw & nw \\
\hline $16 \mathrm{~h}$ & Further wilt & nw & nw \\
\hline $72 \mathrm{~h}$ & Further wilt & nw & nw \\
\hline
\end{tabular}

nw- no wilt seedlings in control sets (un-inoculated Czapek Dox broth medium and sterilized distilled water) showed no symptoms of wilt throughout the experiment (figure 11). Rather, within 72 hours the control seedlings showed marked increase in shoot length as compared to treated seedlings which remained stunted. Also, the treated seedlings showed progressive flaccidity and stooping down with time as indicated by the tabular representation (table 3). Yellowing of seedlings was not observed.

The results indicate that $F$. oxysporum had released toxic or inhibitory molecule(s) in the medium which directly affected metabolic activities of seedling through the root system. These molecules may be responsible for wilt symptoms and inhibition of growth observed in the treated seedlings.

Studies by various researchers suggest that Fusarium species have been known for a long time to produce secondary metabolites toxic to plants (phytotoxins) such as fusaric acid, trichothecenes, fumonisins and enniatins (Roncero et al., 2003). Fusaric acid produced by many Fusarium species was one of the first fungal metabolites implicated in pathogenesis to plants. Role of fusaric acid has also been addressed in vascular wilt of other commercially important plants (Gaumann, 1958; Roncero et al.,2003).

Sibtain et al. (2001) stated that culture filtrate containing Fusarium phytotoxins are helpful in studying level of resistance or susceptibility of hosts to Fusarium. Ravikumar and Babu (2007) admit that fusaric acid is a well known phytotoxin produced by several pathogenic strains of Fusarium oxysporum, the causal organism of wilt in an enormous variety of plants. Jedryczka (1996), besides fusaric acid , isolated two other compounds from pathogenic strains of $F$. oxysporum f. sp. pisi . They were phenylacetic acid and methyl p- hydroxyl phenylacetate but their phytotoxicity was lower than that of fusaric acid.

nW- no wilt

$$
\text { (n) }
$$


Note : No yellowing was seen in any of the sets throughout the experiment. On transferring the wilted plants to distilled water and to uninoculated medium, no sign of recovery was observed.

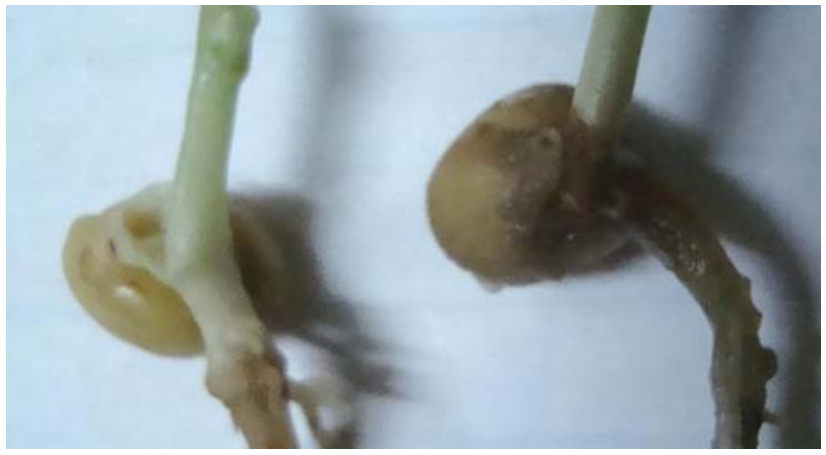

Fig 10: Comparing a healthy pea seedling with a severely infected one. The hypocotyl and epicotyl region showing Fusarium rot symptoms.



Fig 11: Wilt symptoms observed in pea seedling (left) after about three hours of CFCF application. Shrivelled leaflets and drooping down of stem is noticed manifesting presence of Fusarium toxins, while, the seedling in control-medium remained healthy.

Direct Seed to Seed Transfer of Pathogen: It was found that Fusarium propagules which were dormant in the infected seed tissue for several weeks were capable of germinating and infecting fresh seeds on contact. They were found to infect seed coat of the seeds and, in certain cases, radical of the germinated seeds showed red brown lesion at the tip (figure 12).

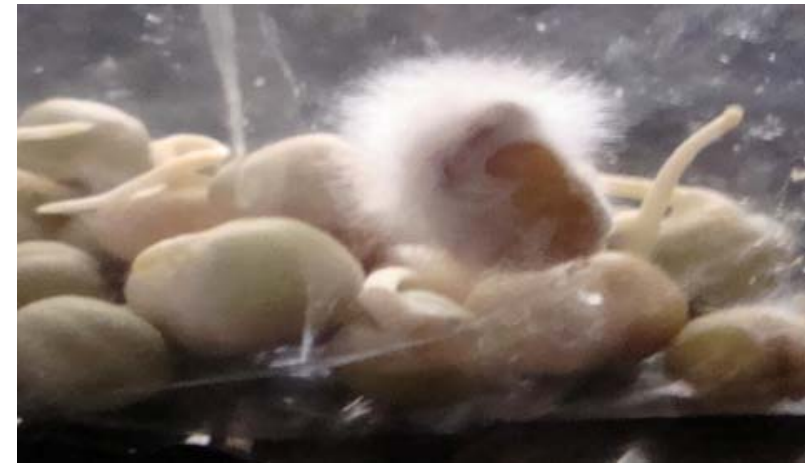

Fig 12: Seed to seed transfer of $F$. oxysporum propagules and germination on host under favourable conditions.

An accelerated spread of pathogen was noticed from a single infected seed to the other healthy seeds within a span of one week. This is specifically important in processing, packaging, storage and transportation conditions of pea seeds in market.

The phenomenon points out that Fusarium has the capacity to stay in dormant state until it gets its host. When in proximity to its host under suitable conditions, it can proliferate readily and can also initiate infection. Kraft, in 1994, mentioned that most formae speciales of Fusarium oxysporum exist as chlamydospores, which are dormant in decaying host tissue and soil until they receive stimulation to germinate. Propagules can remain in soil for years in absence of host in a dormant state (Roncero et al., 2003). Germination may be affected under circumstances where pathogen infects seed before germination at embryonic axis as mentioned previously.

Microscopic Study of Infected Root Tip: Fusarium infected root tip showing red brown decay lesion was studied under microscope. The infected root tip showed disruption of root epidermis. The cells were in the form of debris indicating decay. There were irregularly scattered depositions or debris. The cell walls had lost rigidity and structure. Fungal mycelia were also found amidst the decayed tissue (figure $13 \mathrm{~A}$ ). In comparison, the healthy root tip showed regular, un-punctured and well defined epidermis, rigidity in structure and no irregularly scattered depositions. No fungal mycelia were seen in the tissue which represented homogeneity in thickness and structure (figure $13 \mathrm{~B}, 13 \mathrm{C}$ ). 

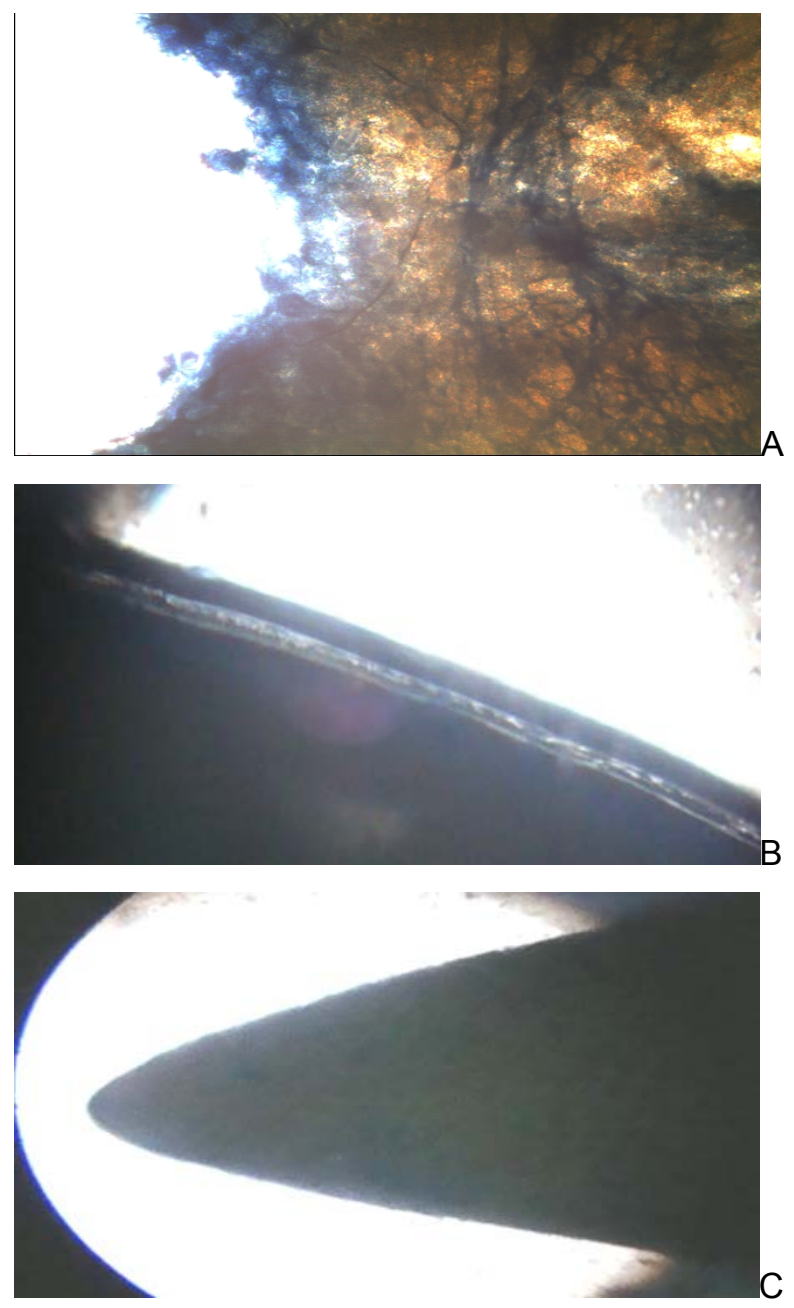

Fig 13: A: Decay of root tip tissue observed and fungal mycelia seen amidst macerated tissue debris. B: Healthy root tip, un-punctured epidermal layer and C: Healthy and intact root tip

Differences between infected and healthy root tips are clear and substantiate that on invasion by pathogenic fungi, plant defence mechanism induces thickening of cell wall by deposition of materials. The host cells are signalled to protect themselves by swift stimulation of a general surge of nonspecific defence responses (Benhamou and Garand, 2001). Schippers and Voetberg (1969) found that epidermis and cortex cells of roots of both susceptible as well as resistant varieties of pea respond to penetration by pathogenic $F$. oxysporum f. sp. pisi by synthesizing a cellulose thickening of cell wall which is further infiltrated by lignin like material. A pathogenic strain of $F$. oxysporum can dissolve this deposition in cell wall by secreting cell wall degrading enzymes and make its entry into a susceptible host (Roncero et al., 2003). Fungi form mycelial math on the root tip (Kroes et al., 1998). A resistant host can restrict the further advancement and invasion of fungi into host tissue, through its array of defence mechanisms but a susceptible host is unable to effectively hinder the encroachment of pathogen.

Root infection is initiated in a susceptible host mainly in the zone of elongation immediately behind the root apex which is the most vulnerable region of root while rest of the root is relatively less susceptible (Gunawardena and Hawes, 2002; Gunawardena et al., 2005). Root tips are protected from fungal infection by the synthesis of root border cells. Gunawardena et al. (2005) studied that infection by pathogenic Fusarium resulted in death of border cells concurrent with production of a factor which inhibited fungal growth. They also suggested that presence of root border cells along with mucilage may form a physical barrier. Hawes et al., in 2002, mentioned the role of root border cells in host specificity shown by pathogen. They stated that only those micro organisms can access border cells which carry genes required to recognize substances contained inside border cells and can respond to the signals released by these cells. Exudates from root cap and border cells were found to be critical in host selection, pathogen spore germination and mycelial coverage (mantle formation) of root tip. Also, it was stated that mantle formation occurred only when a pathogenic fungus interacted with a susceptible host.

In case, the border cells and other plant defence mechanisms fail to contain the pathogen, the pathogen progresses further and shows its virulence through its toxins and cell wall degrading enzymes (CWDEs). F. oxysporum secretes a defined sequence of extracellular CWDEs. Pectate lyase being one of them has been suggested to be important in vascular wilt diseases (Beckman, 1987; Roncero et al.,2003).

Determining Alternate Harbours: Germination was not hindered by the test pathogen in any of the plants taken under study. Cicer arietinum, Glycine max and Solanum lycopersicon showed mycelial growth on seed coat indicating that molecules in the seed exudates are not showing any resistance to growth of the test fungus on coat while other seeds did show considerable resistance to the fungus. Lesions on radical tip and wilt of seedling were observed in all the test plants (table 4, figure 14). 
Table 4: Determining Alternate Harbours of Fusarium oxysporum f. sp. pisi

\begin{tabular}{|l|l|l|l|l|}
\hline Seeds (Plant name) & $\begin{array}{l}\text { Seed } \\
\text { germination }\end{array}$ & Fungal Growth on seed coat & $\begin{array}{l}\text { Lesion on } \\
\text { radical/ roots }\end{array}$ & $\begin{array}{l}\text { Wilting of } \\
\text { seedling }\end{array}$ \\
\hline Cicer arietinum & + & + & + & + \\
\hline Glycine max & + & + & + & + \\
\hline Solanum lycopersicon & + & + & + & + \\
\hline Vigna radiate & + & - & + & + \\
\hline Cajanus cajan & + & $\begin{array}{l}\text { (feeble mycelia growth after three } \\
\text { days) }\end{array}$ & + & + \\
\hline Vigna mungo & - & + & + \\
\hline
\end{tabular}

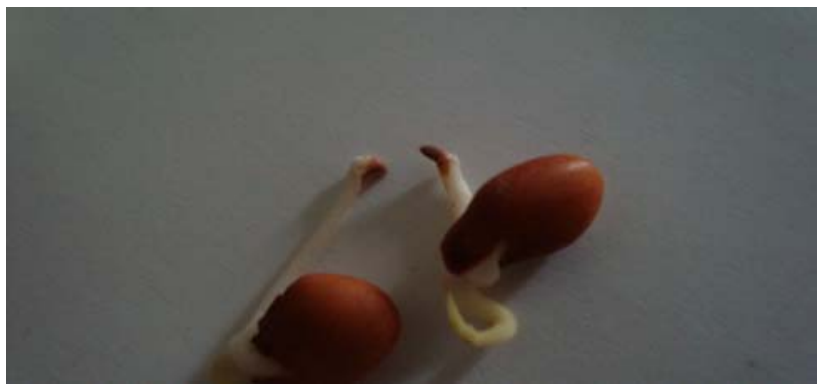

Fig 14: Red mung beans (Vigna radiata) seeds showing brown lesions on radical caused by $F$. oxysporum F/G02 infection.

F. oxysporum FP-02/G showed severe disease symptoms on pea but milder symptoms on other crops. These differences are attributed to the differences in germinating seed exudates which in turn are determined by plant genotype (FunckJensen, 1984).

Lesions were seen on root tips of all the sprouts. These lesions could be a result of non specific defence mechanisms usually shown against an intruding fungus. If the fungus is able to cross this barrier, only then the infection proceeds further (Gunawardena et al., 2005). Although, when the same sprouts showing lesions on radical tips were planted in soil they showed normal growth. Wilting of seven day old seedlings by Fusarium metabolite is an indication but not particularly a confirmation of susceptibility to the pathogen as non specific toxins of Fusarium such as fusaric acid can induce wilting in a range of plants (Ravikumar and Babu, 2007).

Under in vitro conditions, where the density of pathogen may be higher, environmental conditions are artificially set, genuine complex interactions among abiotic and biotic factors are lacking, one cannot assure the susceptibility of a test plant towards the pathogen. Yet, considering the results in determining alternate harbours, one cannot rule out the possibility of $F$. oxysporum f. sp. pisi (FP$02 / G$ ) extending its host range in this region.

Buxton (1958) stated in his article, " A striking feature of Fusarium wilts is their sudden occurrence in crops in which they were previously unknown." It was also mentioned by the researcher that such new outbreaks suggested that either saprophytic forms of the fungus have turned parasitic or existing parasitic races have extended their host range. And, one important reason of this could be high mutability of Fusarium species.

Menzies et al. (1990) screened several plant species for susceptibility to $F$. oxysporum f. $\mathrm{sp}$. radicislycopersici and found that the pathogen had a broad host range containing both symptomless hosts and hosts displaying only mild symptoms of infection. These hosts may act as reservoirs of the pathogen until highly susceptible hosts are available for infection. This fact has also been supported by studies conducted by Chongo et al. (2001) on host range of Fusarium graminearum. The spontaneous clustering of virulence genes in Fusarium as well as presence of putative transposable elements is a matter of apprehension. Researchers suggest that horizontal transfer of such pathogenicity gene clusters may bestow the competence to infect new host plants (Han et al., 2001).

Seed and root exudates can be imperative in determining the microbial flora in the rhizosphere and rhizoplane of a plant. In situations where the exudates support antagonistic microbes rather than the pathogen, intrusion of plant roots by pathogen can be prevented (Funck-Jensen 1984).

In the present research, characteristic yellowing and necrosis symptoms were observed in pea plants in the afflicted agricultural fields taken under survey, but under laboratory conditions these attributes were not very prominent. Although, many researchers maintain that phytotoxin production is largely responsible for yellowing (degradation or inhibition of chlorophyll 
synthesis), wilting and necrosis symptoms observed in afflicted plants (Andre, 1997; Khan et al., 2004). Culture filtrate of $F$. oxysporum f. sp. ciceris was shown to inhibit synthesis of chlorophyll in legumes such as chickpea by Khan et al. (2004). According to Slavov (2005), genetic and biochemical studies reveal that at least to an extent phytotoxins of pathogen may be determinants of specificity in plant - pathogen interaction and if toxin is not in purified form for the studies, culture filtrate of pathogen can be used as selective agent.

When a host plant is attacked by a pathogen an assortment of defence mechanisms are triggered in the target cells which convey signals to surrounding cells and, further on, resulting in localized or systemic resistance depending on the defence related genes activated. Defence related genes encode a range of proteins including enzymes controlling secondary metabolism, pathogenesis related proteins (PR) and regulatory proteins that control the expression of other defence related genes (Dixon et al., 1994; Raju, 2008). The defence gene products include enzymes such as polyphenol oxidase, peroxidase that catalyze the formation of lignin, and phenylalanine ammonia lyase that is involved in production of phytoalexins and phenolics. Some other defence enzymes include pathogenesis related proteins such as beta-1,3glucanases (PR-2 family) and chitinases (PR-3 family), which degrade the fungal cell wall and cause lysis of fungal cell. Chitin and glucan oligomers released during degradation of fungal cell wall act as an elicitors of various defence mechanisms in plants (Frindlender et al., 1993; Raju, 2008). Delaney et al. (1995) stated that salicylic acid is a natural phenolic component in the signal transduction pathway involved in local and systemic resistances to pathogens.

Since plants are capable of pooling their defence mechanisms to combat and stymie the attacking pathogen. The pathogen can succeed in infecting and causing disease only if it is able to breach these plant defences. A complex interaction between the plant defence systems and pathogen virulence factors take place. The outcome of this interaction is manifested as 'disease or no disease'.

In order to initiate disease in the host, the pathogen must follow a chain of events beginning from recognition of host signals, attachment of the pathogen to root surface followed by degradation of physical barriers of host such as cuticle and cell wall. The pathogen must be able to withstand the host antifungal compounds and also produce phytotoxins to interfere with plant metabolism. In the first step, the pathogen senses stimuli from the plant through cell receptors and signal transduction cascades which control the expression of effector genes that are directly implicated in pathogenesis. Cutin is the first signal molecule from plant recognized as inducer of fungal pathogenicity response. Cutin induces production of extracellular cutinase in fungi, leading the way to puncture plant cuticle (Roncero et al., 2003). The next step is to puncture the cell wall. It was found by Jones et al. (1972) that F. oxysporum secretes a defined sequence of extracellular cell wall degrading enzymes when brought in contact with its host cell wall. Pectate lyases which depolymerise pectin is suggested to be important in vascular wilt diseases caused by Fusarium species. Polygalacturonases produced by $F$. oxysporum depolymerises homogalacturan which results in effective maceration of plant tissue. F. oxysporum produces xylanolytic enzymes to depolymerise xylan which is also a major component of plant cell wall (Alconada and Martinez, 1994; Ruiz et al., 1997).

Besides puncturing and macerating cell wall of host it is also necessary for the pathogen to detoxify the plant defence molecules called phytoanticipins and phytoalexins in order to survive in the host tissue. Pisatin; phytoalexin produced by pea is detoxified by pisatin demethylase activity of Fusarium (Hadwiger, 2008). High level of this activity is suggested to be directly associated with virulence of Fusarium (van Etten et al., 1989). Lesion development on roots of pea is also attributed to this factor (Schäfer et al., 1989). Fusarium might adopt protective mechanisms such as alteration in their own cellular components which are targeted by the toxic metabolites of plants (Defago et al., 1983). Also, activation of membrane transporters may prevent the accumulation of toxic chemicals in the fungal pathogen by continuously eliminating these deleterious plant metabolites from fungal cells (Del Sorbo et al., 1997; Urban et al.,1999). Once the pathogen has disarmed the host, it attacks by producing phytotoxins which are an important virulence factor. And thereafter, proliferates inside the host.

The genome of Fusarium oxysporum is considered to show high degree of instability attributed to its transposable elements. Chromosome rearrangement mediated by transposon has been studied in $F$. oxysporum. This suggests that transposable elements could be agents of rapid genomic reshuffle in natural populations of $F$. oxysporum, consequently 
providing an adaptive suppleness for this fungus (Daviere et al., 2001).

\section{Confirming Identity of the Most Virulent Pathogen FP-02/G Isolated from Pea}

Identity of the most virulent Pathogen FP-02/G isolated from diseased root of pea, obtained from village - Ghana, District- Jabalpur, was confirmed. Cultural characteristics on obverse side of PDA medium, showed abundant mycelia, floccose, white to pale violet in colour with age of culture. Reverse side showed characteristic pigmentation, magenta to wine red to violet colour with age of culture. Microscopic features include Macroconidia- slightly curved, slender and thin walled, tri-septate, pointed ends. Microconidia- abundant, oval to kidney shaped, non-septate. Conidiophore- short, monophialide. Chlamydospores- seldom present, globose, intercalary.

This pathogenic fungus caused severe disease symptoms in pea but showed mild symptoms on other plants. On the basis of these characteristics the pathogen isolate FP-02/G was identified as Fusarium oxysporum f.sp. pisi. The identity of isolate FP-02/G was confirmed as Fusarium oxysporum by Mycology and Plant Pathology Group, Agharkar Research Institute, Pune, India. The pathogen has been deposited by the institute under accession number NFCCI-2195.

\section{CONCLUSION}

Fusarium wilt diseases still remain a problem in modern agriculture. Excessive use of chemical fungicides may apparently lower the density of pathogens in soil in short time duration but might give rise to mutant strains of pathogens with altered pathogenicity; making the previously resistant varieties of crops susceptible. Use of biocontrol methods, crop rotations and genetically modified crops are some of the methods of disease management to curb down extreme use of chemicals on field to control pathogens.

\section{ACKNOWLEDGEMENT:}

I thank all the farmers of Jabalpur district for their cooperation in survey and sampling of pea cultivations. I also extend my gratitude to Fungal Identification Service, Agharkar Research Institute, Pune, India for their services.

\section{REFERENCES}

Agarwal, V.K. and Sinclair, J.B (1987). Mechanism of seed infection in Principles of seed pathology. CRC Press, Inc. p. 176.
Alconada, T.M. and Martinez, M.J (1994). Purification and characterization of an extracellular endo-1,4- $\beta$-xylanase from Fusarium oxysporum f. sp. melonis. FEMS Microbiology Letters, 118: 305-310.

Andre, F (1997). Structure and activity of a natural phytotoxin, tentoxin. New insights in enzymatic mechanism of chloroplast $\mathrm{H}+$ ATP-synthase. Comptes Rendus des Seances de la Societe de Biologie et de ses Filiales, 191: 401-432.

Basu, P.K., Brown, N.J., Crete, R., Gourley, C.O., Johnston, Pepin, H.S. and Seaman, W.L (1976). Yield loss conversion factors for Fusarium root rot of pea. Canadian Plant Disease Survey, 56: 25-32.

Basu, P.K., Crete, R., Donaldson, A.G., Gourley, C.O., Haas, J.H., Harper, F.R., Lawrence, C.H., Sesman, W.L., Toms, H.N.W., Wong, S.I. and Zimmer, R.C (1973). Prevalence and severity of diseases of processing peas in Canada, 1970-71. Canadian Plant Disease Survey, 53: 49-57.

Beckman, C.H (1987). The nature of wilt disease of plants. American Phytopathological Society, St. Paul, MN.

Benhamou, N. and Garand, C (2001). Cytological analysis of defense-related mechanisms induced in pea root tissues in response to colonization by non-pathogenic Fusarium oxysporum Fo47. Phytopathology, 91: 730-740.

Buxton, E. W. and Storey, I. F (1954). The occurrence of pea wilt in Britain. Plant Pathology, 3: 13-16.

Buxton, E.W (1958). A change of pathogenic race in Fusarium oxysporum f. pisi induced by root exudates from a resistant host. Nature, 181: 1222-1224.

Chongo, G., Gossen, B.D., Kutcher, H.R., Gilbert, J., Turkington, T.K., Fernandez, M.R. and McLaren, D (2001). Reaction of seedling roots of 14 crop species to Fusarium graminearum from wheat heads. Canadian Journal of Plant Pathology, 23: 132-137.

Clarkson, J.D.S (1978). Pathogenicity of Fusarium spp. associated with foot-rots of peas and beans. Plant Pathology, 27(3): 110-117.

Daviere, J.M., Langin, T. and Daboussi, M.J (2001). Potential role of transposable elements in the rapid reorganization of the Fusarium oxysporum genome. Fungal Genetics and Biology, 34: 177-192.

Defago, G., Kern, H. and Sedlar, L (1983). Genetic analysis oftomatine insensitivity, sterol content and pathogenicity for green tomato fruits in mutants of Fusarium solani. Physiological and Molecular Plant Pathology, 22: 39-43.

Del Sorbo, G., Andrade, A.C., Van Nistelrooy, J.G., Van Kan, J.A., Van Kan, Balzi, E. and De Waard, M.A (1997). Multidrug resistance in Aspergillus nidulans invoves novel ATP-binding cassette transporters. Molecular and General Genetics., 254: 417-426.

Delaney, T.P., Friedrich, L. and Ryals, J (1995). Arabidopsis signal transduction mutant defective in chemically and biologically induced disease resistance. Proc. Natl. Acad. USA. 92: 6602-6606.

Dhingra, O.D. and Sinclair, J.B (1995). Basic Plant Pathology Methods ( Second Ed.). CRC Press Lewis Publishes, Florida. 
Dixon, R.A, Harrison, M.J. and Lamb, C.J (1994). Early events in the activation of plant defense responses. Annual Review of Phyopathology, 32: 479-501.

Felgueiras, M., Dias, A. Chicau, G., Berbega, M., León, M. and Armengo, J (2010). First Report of Fusarium Wilt Caused by Fusarium oxysporum f. sp. basilici on Ocimum minimum in Portugal. Plant Disease, 94 (9) :1,170.1 $1,170.1$

Frindlender, M., Inbar, J. and Chet, I (1993). Biological control of soil borne plant pathogens by a $\beta-1,3$-glucanase producing Pseudomonas cepacia. Soil Biology and Biochemistry, 25: 1211-1221.

Funck-Jensen, D. and Hockenhull, J (1984). Root exudation, rhizosphere microorganisms and disease control. Vaxtskyddsnotiser, 48: 49-54.

Gagkaeva, T (2008). Introduction to Fusarium taxonomy, AllRussian Institute of Plant Protection, St. Petersburg, Russia. http://fou02.planteforsk.no/Fusarium/Presentasjoner

Gaumann, E (1958). The mechanisms of fusaric acid injury. Phyopathology, 48: 670-686.

Gordon, T.R. and Martyn, R.D (1997). The evolutionary biology of Fusarium oxysporum. Annual Review of Phytopathology, 35: 111-128.

Gunawardena, U. and Hawes, M.C (2002). Tissue specific localization of root infection by fungal pathogens: role of root border cells. . Molecular Plant-Microbe interactions, 15(11): 1128-1136.

Gunawardena, U., Rodriguez, M., Straney, D., Romeo, J.T., VanEtten, H.D. and Hawes, M.C (2005). Tissue-specific localization of pea root infection by Nectria haematococca. Mechanisms and consequences. Plant Physiology, 137: 1363-1374.

Hadwiger, L.A (2008). Pea-Fusarium solani interactions contributions of a system toward understanding disease resistance. Phytopathology, 98: 372-379.

Hagedorn, D.J (1991). Handbook of pea diseases A1167.University of Wisconsin- Extension, Madison.

Han, Y., Liu, X., Benny, U., Kistler, H. C. and VanEtten, H. D (2001). Genes determining pathogenicity to pea are clustered on a supernumerary chromosome in the fungal plant pathogen Nectria hamatococca. The Plant Journal, 25: 305-314.

Haware, M.P (1971). Fungal microflora of seeds of Pisum sativum L. and its control. Mycopathologia, 43 (3-4): 343345.

Hawes, M.C., Bengough, G.A., Cassab, G. and Ponce, G (2002). Root caps and rhizosphere. Journal of Plant Growth Regulation, 21: 352-367.

Hayat, F., Hussain, S. and Shah, S.J.A (2005). Detection of seedborne fungi in various pea cultivars grown in Northwest Frontier Province of Pakistan. Sarhad Journal of Agriculture, 21(1): 121-123.

Jedryczka, M (1996). Methods of resistance evaluation and obtaining pea (Pisum sativum L.) genotypes resistant to Fusarium Wilt (Fusarium oxysporum Schlecht. f. sp. pisi [Van Hall] Snyd. Et Hans.). Ph.D. Thesis 1995. Institute of
Plant Genetics, Polish Academy of Sciences, Poznan, Poland. Grain Legumes, 13: 9

Jones, T.M., Anderson, A.J. and Albersheim, P (1972). Hostpathogen interactions. IV. Studies on the polysaccharidedegrading enzymes secreted by Fusarium oxysporum $\mathrm{f}$. sp. lycopersici. Physiological Plant Pathology, 2: 153-166.

Karaca, G. and Kahveci, E (2010). First report of Fusarium oxysporum f. sp. radicis-cucumerinum on cucumbers in Turkey. Plant Pathology, 59 (6): 1173-1174.

Keinath, A.P (1994). Pathogenicity and host range of Fusarium oxysporum from sweet basil and evaluation of disease control methods. Plant Disease, 78(12): 1211-1215.

Khan, I.A., Alam, S.S. and Jabbar, A (2004). Purification of phytotoxin from culture filtrates of Fusarium oxysporum $\mathrm{f}$. sp. ciceris and its biological effects on chickpea. Pakistan Journal of Botany, 36: 871-880.

Kraft, J.M (1994). Fusarium wilt of peas (a review). Agronomie, 14: $561-567$

Kroes, G.M.L.W., Baayen, R.P. and Lange, W (1998). Histology of root rot of flax seedlings (Linum Usitatissimum) infected by Fusarium oxysporum f. sp. lini. European Journal Plant Pathology, 104: 725-736.

Lattanzio, V., Lattanzio, V.M.T. and Cardinali, A (2006). Role of phenolics in the resistance mechanisms of plants against fungal pathogens and insects. Phytochemistry: Advances in Research, pp. 23-67 .Editor: Filippo Imperato, Trivandrum, Kerala, India.

Leslie, J.F. and Summerell, B.A (2006). The Fusarium Laboratory Manual. Blackwell Publishing Ltd., Oxford, U.K.

Manzies, J.G. and Koch, C (1990). Additions to the host range of Fusarium oxysporum f.sp. radicis-lycopersici. Plant Disease, 74(8): 569-572.

Marcinkowska, J (2008). Fungi occurrence on seeds of field pea. Acta Mycologica, 43(1): 77-89.

Masheshwari, S.K., Gupta, J.S. and Jhooty, J.S (1982). Role of seed mycoflora of pea in the wilt and root-rot complex and its pathogenicity. Agricultural Science Digest, 2: 196198.

Menzies, J.G., Koch, C. and Seywerd, F (1990). Additions to the host range of Fusarium oxysporum f. sp. radicislycopersici. Plant Disease, 74: 569-572.

Morrissey, J.P. and Osbourn, A.E (1999). Fungal resistance to plant antibiotics as a mechanism of pathogenesis. Microbiology and Molecular Biology reviews, Sept.: 708724.

Nelson, E.B (1991). Exudate molecules initiating fungal responses to seeds and roots. In: The rhizosphere and plant growth. D.L. Keister and P.B. Cregan (Eds.). Kluwer Academic Publishers, pp. 197-209.

Nelson, P.E (1981). Life cycle and epidemiology of Fusarium oxysporum. In: Fungal Wilt Diseases of Plants (ME Mace, AA Bell, CH Beckman, eds), Academic Press, New York, USA, pp. 51-80.

Ondrej, M., Dostalova, R. and Trojan, R (2008). Evaluation of virulence of Fusarium solani isolates on pea. Plant Protection Science, 44: 9-18. 
Padwick, G.W (1938). Complex fungal rotting of pea seeds. Annals of Applied Biology, 25 (1): 100-114.

Pande, S., Rao, J.N., and Sharma, M (2007). Establishment of the chickpea wilt pathogen Fusarium oxysporum f. sp. ciceris in the soil through seed transmission. Plant Pathology Journal, 23(1): 3-6.

Persson, L., Bodker, L., and Larsson-Wikstrom, M (1997). Prevalence and pathogenicity of foot and root rot pathogens of pea in Southern Scandinavia. Plant Disease, 81(2): 171-174.

Perveen, K., and Bokhari, N (2010). First report of Fusarium wilt of Lavandula pubescens caused by Fusarium oxysporum in Saudi Arabia. Plant Disease, 94( 9): 1,163.2 - 1,163.2.

Polizzi, G., Aiello, D., Guarnaccia, V., Vitale, A., Perrone, G. and Stea, G (2010). First report of Fusarium wilt of Paper Flower (Bougainvillea glabra) caused by Fusarium oxysporum in Italy. Plant Disease, 94(4): 483.1 - 483.1

Raju, S., Jajalakshmi, S.K., and Sreeramulu, K (2008). Comparative study on the induction of defense related enzymes in two different cultivars of chickpea (Cicer arietinum L) genotypes by salicylic acid, spermine and Fusarium oxysporum f. sp. ciceri. Australian Journal Crop Science, 2(3): 121-140.

Ravikumar, R.L. and Babu, D.R (2007). In vitro screening of chickpea genotypes for Fusarium wilt resistance through root feeding of pathotoxin. Current Science, 93(1): 20-22.

Roncero, M.I.G., Hera,C., Ruiz-Rubio, M., Maceira, F.I.G., Madrid, M.P., Caracuel, Z., Calero, F., Delgado-Jarana, J., Roldan-Rodriguez, R., Martinez-Rocha, A.L., Velasco, C., Roa, J., Martin-Urdiroz, M., Cordoba, D. and DiPietro, A (2003). Fusarium as a model for studying virulence in soilborne plant pathogens. Physiological and Molecular Plant Pathology, 62(2): 87-98.

Ruiz, M.C., Di Pietro, A. and Roncero, M.I.G (1997). Purification and characterization of an acidic endo-beta1,4-xylanase from the tomato vascular pathogen Fusarium oxysporum f.sp. lycopersici. FEMS Microbiology Letters, 148: 75-82.

Sardana, S., Mahajan, R.K., Gautam, N.K. and Ram, B (2007). Genetic variability in pea (Pisum sativum L.) germplasm for utilization. SABRAO Journal of Breeding and Genetics, 39(1): 31-41.

Schäfer, W., Straney, D., Ciuffetti, L., van Etten, H.D. and Yoder, O.C (1989). One enzyme makes a fungal pathogen, but not a saprophyte, virultent on a new host plant. Science, 246: 247-249.

Schippers, B. and Voetberg, J.S (1969). Germination of chlamydospores of Fusarium oxysporum f. sp. pisi race 1 in the rhizosphere, and penetration of the pathogen into roots of a susceptible and a resistant pea cultivar. Netherlands Journal of Plant Pathology, 75(4): 241-258.

Short, G.E. and Lacy, M.L (1974). Germination of Fusarium solani f. sp. pisi chlamydospores in the spermosphere of pea. Phytopathology, 64: 558-562.
Sibtain, M. Ilyas, M.B., Khan, I.A. and Alam, S.S (2001). Screening of chickpea germplasm against Fusarium wilt in pot soil water culture and cultural filtrate. Journal of Biological Sciences, 1(4): 229-231.

Skovgaard, K., Bodker, L. and Rosendahl, S (2002). Population structure and pathogenicity of members of the Fusarium oxysporum complex isolated from soil and root necrosis of pea (Pisum sativum L.). FEMS Microbiology Ecology, 42(3): 367-374.

Skovgaard, K., Rosendahl, S., O'Donnell, K. and Nirenberg, H. I (2003). Fusarium commune is a new species identified by morphological and molecular phylogenetic data. Mycologia, 95(4): 630-636.

Slavov, S (2005). Phytotoxins and in vitro screening for improved disease resistant plants. Biotechnology and Biotechnological Equipments, 19: 48-55.

Smartt, J (1990). Grain Legumes: Evolution and Genetic resources. Cambridge University Press, Cambridge, UK.

Smith, S.N (2007). An overview of ecological and habitat aspects in the genus Fusarium with special emphasis on the soil-borne pathogenic forms. Plant Pathology Bulletin, 16: $97-120$.

Snyder, W.C (1932). Seed dissemination in Fusarium wilt of pea. Phytopathology, 22: 253-257.

Snyder, W.C (1933). Variability in the pea-wilt organism, Fusarium orthoceras var. pisi. Journal of Agricultural Research, 47(2)

Staggs, L., St. Leger, J., Bossart, G., Townsend Jr, F. I., Hicks, C. and Rinaldi, M (2010). A novel case of Fusarium oxysporum infection in an Atlantic Bottlenose Dolphin (Tursiops truncatus). Journal of Zoo and Wildlife Medicine, 41(2): 287-290.

Stasz, T.E., Harman, G.E. and Marx, G.A (1980). Time and site of infection of resistant and susceptible germinating pea seeds by Pythium ultimum. Phytopathology, 70: 730733.

Summerell, B.A., Salleh, B. and Leslie, J.F (2003). A utilitarian approach to Fusarium identification. Plant Disease, 87(2):117-128.

Tessier, B.J., Mueller, W.C. and Morgham, A. T (1990). Histopathology and ultrastructure of vascular responses in peas resistant or susceptible to Fusarium oxysporum $\mathrm{f}$. sp. pisi. Phytopathology, 80: 756-764.

Urban, M., Bhargava, T. and Hamer, J.E (1999). An ATPdriven efflux pump is a novel pathogenicity factor in rice blast disease. The EMBO Journal, 18: 512-521.

van Etten, H.D., Matthews, D.E. and Matthews, P.S (1989). Phytoalexin detoxification: importance for pathogenicity and practical implications. Annual Review of Phytopathology, 27: 143-164.

Watanabe T (2002). Pictorial Atlas of Soil and Seed Fungi. Second edition. CRC Press, USA. 